\title{
INTEGRAL ACCOUNT AND AGROECONOMIC APPLICATION OF AN INTRODUCTORY INTEGRAL
}

Ivan Milojević ${ }^{1}$, Svetlana Ignjatijević ${ }^{2}$, Mihailo Ćurčić ${ }^{3}$

*Corresponding author E-mail: curcicmihailo@gmail.com

A R T I C L E I N F O
Review Article
Received: 23 March 2019
Accepted: 09 June 2019
doi:10.5937/ekoPolj1902579M
UDC 517.4:657.372

Keywords:

Agroeconomic phenomena, integral analysis

JEL: C69, D49

\section{A B S T R A C T}

Agroeconomic events follow the formation of relationships in the society regarding transactions that occur in market systems. Integration as a mathematical operation has wide application in solving certain agroeconomic changes.

The dependence of application of integration in certain agroeconomic functions takes the dominant position in solving real problems. In this connection, we will show the application of an unspecified integral in some agroeconomic events. What will we try to contribute to the application of this kind of quantitative analysis on agroeconomic factors.

C 2019 EA. All rights reserved.

\section{Introduction}

Agroeconomic policy is an important segment of the overall macroeconomic policy of every society. The investigation of the phenomenon from this segment requires the application of the equimetric and quantitative models. Due to the evident domination of the marginalist economic direction, such research is gaining in importance.

The subject of this paper is to demonstrate the possibility of applying an integral account in the research of agroeconomic phenomena and processes.

Integration is an inverse operation from differentiation. Integration sign $\int$ is an elongated letter $S$. This symbol is not arbitrarily selected as, for instance, a symbol $\sqrt[n]{ }$ for the root. An elongated letter $S$ shows that this is a surgery that has a similarity

1 Ivan Milojević, PhD, Professor, University of Defense, Military Academy, Pavla Jurišića Šturma street No. 33, Belgrade, Serbia, +381690702697, drimilojevic@gmail.com, https:// orcid.org/0000-0003-3653-3477?lang=en

2 Svetlana Ignjatijević, $\mathrm{PhD}$, Associate Professor, Faculty of Agroeconomics and Engineering Management, Cvećarska street No. 2, Novi Sad, Serbia, +38121400484, ceca@fimek.edu.rs, https://orcid.org/0000-0002-9578-3823

3 Mihailo Ćurčić, MA, Teaching Assistant, University of Defense, Military Academy, Pavla Jurišića Šturma street No. 33, Belgrade, Serbia, +381654009049, curcicmihailo@gmail.com, https://orcid.org/0000-0001-7674-0310 
to summation, such as differentiation analogous to subtraction. In fact, it has been shown beforehand that it is a differential $d y$ approximately equal to the difference $\Delta y=y_{2}-y_{1}$.

If two inverse operations are executed successively over a certain size, for example, over a variable, then their operation is canceled and the size remains unchanged, i.e. $\int d x=x+C, C$ - integration constant.

The reason that along with the appearance of one more arbitrary constant, it is easy to understand. Actually, $d x=d(x+C)$ then $\int d x=\int d(x+C)=x+C$. Otherwise, this constant is indeterminate and according to it, the integral is called an indefinite integral. This inverse operation from differentiation can also be understood in the following way. Under the sign $\int$ is the difference, i.e. product derivative of function and differential of independent variables. In our previous assumption, the copy is equal 1. Therefore, the integration here meant determining a function whose output is equal to the unit. And what function does it have as a copy of 1? This, obviously, is not just a function $y=x$ but also all linear functions of the form $y=x+C$. Integration is, therefore, reduced to the search for a function whose derivative is known. In other words, integration is the search for a primitive function, primitive in terms of the original.

Integration, however, is not that simple at all. In order to solve the integrals of more complex functions, it is not enough to know just the rules of differentiation.

By systematizing knowledge in the field of the integral account, significant starting points for each research can be obtained.

\section{Literature review}

The application of integral analysis in agroeconomic processes establishes a systematically marginalistic approach to the quantitative study of the process of this scientific whole (Daze, 2008).

By studying the possibility of integral modeling of the optimal development of large systems. (Markova et al., 2019) as the subject of the integral application takes the age structure of equipment according to certain types. In the case of such an integral application, it is possible to investigate and set the boundaries of integration in the agro-industry complex in order to find a replacement solution for the numerical way by optimizing the cost of replacement.

Finding Convertible Relations as the Basis of Production of the Agro-Industrial Complex makes the application of the integration conditional on the case of investment construction (Cevi et al., 2010) in the process of evaluating the investment of a continuous tubular model with a plastic blanket for pig breeding, and it came to the 
conclusion that the technical The dimension has a major impact on the results and economic development.

A competitive environment imposes a need for a constant analysis of inflows and outflows of money. Due to the need to retain existing investors, a new attraction is imposed by the need for the application of analytical methods (Knežević et al., 2016). The agroindustrial complex fulfills all the necessary conditions to be the subject of analysis, contrary to the turbulent modern business. Investors monitor the inflows and outflows of money due to which they make their business decisions.

The agro industry encompasses all activities starting from harvests, transformation, storing and preparation of agricultural raw materials for production or final consumption (Wohlmuth, Kormawa, 2012). The main focus is on production and food processing, but it should not be wrongly identified with the food industry, which is processing agricultural raw materials into food and beverages (FAO et al., 2008).

In order for the development of the agro industry to be efficient, there are some necessary structural changes in agriculture and the food industry which are required. Although they are time consuming and financially demanding, the practice shows that they are manageable, but with an inadequate support of agrarian and industrial policies. (Savić et al., 2016)

Taking into consideration that this paper is concerned with proving connection and interaction between integral account and introductory integral, it can be stated that the main subject of a correlation analysis is to examine the mutual strength of the relationship and the dependence between the variables. According to Durkalic and Ćurčič (2019), the examination of the direction and strength of the interaction is carried out on the basis of a correlation analysis.

\section{Materials and methods}

From the rule for the sum of differentials $d[u(x)+v(x)]=d u(x)+d v(x)$ i the fact that the differentiation and integration of mutually inverse operations is followed

$$
\int[d u(x)+d v(x)]=\int d[u(x)+v(x)]=u(x)+v(x)=\int d u(x)+\int d v(x)
$$

ie. the integral of the sum equals the sum of the integral of the collection (Babic et al., 1996). In the same way, the rule according to which the integral of the difference is equal to the difference of the integral is performed.

If we read the following rule: $d[k f(x)]=k \cdot d f(x)$, apply to this equation operator $\int$, we get that $\int k f(x)=\int d[k \cdot f(x)]=k \int d f(x)$, ie. the integral of a product of a constant and some function is equal to the product of the constant and the integral of this function. (Drenovak, 1999) 
Now, any whole rational function can be integrated. (Ivović, 1999). For instance

$$
\begin{aligned}
& \int\left(3 x^{4}+5 x^{3}-x^{2}+1\right) d x=3 \int x^{4} d x+5 \int x^{3} d x-\int x^{2} d x+\int d x= \\
& =\frac{3}{5} x^{5}+\frac{5}{4} x^{4}-\frac{1}{3} x^{3}+x+C
\end{aligned}
$$

If the operator is applied $\int$ on both sides of the formula:

$$
d[u(x) \cdot v(x)]=v(x) d u(x)+u(x) d v(x)
$$

is obtained, (and by applying the rule for integral sums)

$=\int v(x) d u(x)+\int u(x) d v(x)$.

That's it

$$
\int u(x) d v(x)=u(x) \cdot v(x)-\int v(x) d u(x)
$$

or shorter

$$
\int u d v(x)=u \cdot v-\int v d u
$$

This is the formula for partial integration.

When to determine $\int x^{2} e^{x} d x$ with partial integration, (Martić, 1976) then applying the rule is obtained

$$
\int x^{2} e^{x} d x=x^{2} e^{x}-\int e^{x} 2 x d x
$$

where $u=x^{2}$ and $d v=e^{2} d x$, and integral from the right side is

$$
\int 2 x e^{x} d x=2 \int x e^{x} d x=2\left(x e^{x}-\int e^{x} d x\right)=2\left(x e^{x}-e^{x}\right)+C
$$

and finally

$$
\int x^{2} e^{x} d x=x^{2} e^{x}-2\left(x e^{x}-e^{x}\right)+C
$$

From the first order it can be seen that integrating a function $x^{2} e^{x}$ performed only partially. The integral remained $\int 2 x e^{x} d x$, which is certainly simpler than the starting integral (Atash et al., 2017). In the next order, the determination of this integral is reduced to the determination of an even simpler integral $\int e^{x} d x$. So we complete the 
integration of the function $x^{2} e^{x}$ come a series of partial integration. The result is being monitored:

$$
\begin{aligned}
& \quad\left[x^{2} e^{x}-2\left(x e^{x}-e^{x}+C\right)\right]^{\prime}=2 x e^{x}+x^{2} e^{x}-2\left(e^{x}+x e^{x}-e^{x}\right)= \\
& =2 x e^{x}+x^{2} e^{x}-2 x e^{x}=x^{2} e^{x},
\end{aligned}
$$

ie. the integral derivative is equal to the subintegral function (Kožul, 2017).

If necessary to determine $\int \ln x d x$ using partial integration, then applying the integration rule is obtained $\int \ln x d x=x \ln x-\int x \cdot \frac{1}{x} d x=x \ln x-x+C$, where $u=\ln x$ and $d v=d x$.

The result obtained is checked through

$$
(x \ln x-x+C)^{\prime}=\ln x+x \cdot \frac{1}{x}-1=\ln x .
$$

From the rule for differentiating the complex function $y=f(u(x))$, then from

$$
d f(u(x))=f_{u} \cdot u_{x} d x,\left(\text { where } u_{x} d x=d u\right),
$$

it follows

$$
\int f_{u} \cdot u_{x} d x=\int f^{\prime}(u) d u=f[u(x)]+C
$$

which is a form for the substitution method (Damnjanović et al., 2018.).

By the method of substitution we can determine

$\int \sin 2 x d x$

applying the integration rule

$$
\begin{aligned}
& \left.\int \sin 2 x d x={ }_{(\text {where }} 2 x=u_{\text {and }} 2 d x=d u\right) \text { it follows } \\
& =\frac{1}{2} \int \sin u d u=-\frac{1}{2} \cos u+C=-\frac{1}{2} \cos 2 x+C
\end{aligned}
$$

If it is necessary to determine $\int \operatorname{ctg} x d x$ substitution method by applying the rule of trace (Leković et al., 2018)

$$
\int \operatorname{ctg} x d x=\text { (where } \ddot{\mathrm{u}} \quad x=u \text { and } \cos d x=d u \text { ) it follows: }
$$


$=\int \frac{d u}{u}=\ln u+C=\ln \sin x+C$

This result can be generalized. Instead of $\frac{\cos x}{\sin x}$ it should be taken generalized $\frac{f^{\prime}(x)}{f(x)}$ , ie. a fraction that has a function in the directory, and in the brochure a copy of that function. It was then

$$
\int \frac{f^{\prime}(x)}{f(x)} d x=\ln f(x)+C
$$

By supstitution method (Jovanović et al., 2017) it can be defined $\int \sin ^{5} x \cos x d x$ where the application of the rule is obtained

$$
\int \sin ^{5} x \cos x d x=
$$

(where $\sin x=u$ and $\cos d x=d u$ ) it follows

$=\int u^{5} d u=\frac{u^{6}}{6}+C=\frac{\sin ^{6} x}{6}+C$.

It's generally valid: $\int f^{n}(x) \cdot f^{\prime}(x) d x=\frac{f^{n+1}(x)}{n+1}+C$.

\section{Results and Discussion}

Let's take some surface of the land or machines $R_{1}, R_{2}, R_{3}, \ldots, R_{n}$ dinars rent at the end of this year, or at the end of each of the following $n-1$ year. The present value $A$ of such an annuity is the same

$$
A=R_{1} r^{-1}+R_{2} r^{-2}+\ldots+R_{n} r^{-n}=\sum_{k=1}^{n} R_{k} r^{-k}
$$

provided that the compound interest is calculated decisively and that the interest rate in that period is constant. If it is $R_{k}=$ const.,$(k=1,2, \ldots, n)$, then it is

$$
A=R \sum_{k=1}^{n} r^{-k}=R \frac{1}{r^{n}} \frac{r^{n}-1}{r-1}=R I V_{p}^{n} .
$$

Suppose an annuity does not arrive at a discontinuous, leapfrog at the end of each year, but runs continuously throughout the year. Let her get the way every year after 
$R$ dinars. Then it comes approx $R \frac{1}{365}$ dinars per day, $R \frac{1}{365 \cdot 24}$ dinars per hour etc., then $R \cdot \Delta t$ dinars per small time interval $\Delta t$.

If rent $R \cdot \Delta t$ comes after $t$ years, starting today (when $t=0$ ), ie. in the interval $t, t+\Delta t$, then its present value, with continuous interest, is approximately equal

$$
R \cdot \Delta t e^{-\frac{p t}{100}}
$$

What is the current annuity value over the entire interval of $t=0$ do $t=x$ years.

Obviously, it is roughly equal to the sum: $\sum_{\Delta t \in[0, x]} R e^{-\frac{p t}{100}} \cdot \Delta t$.

Symbol $\Delta t \in[0, x]$ shows that it is supposed to be summed over time intervals $\Delta t$ from $t=0$ to $t=x$.

If $\Delta t \rightarrow 0$, sum converges the integral $\int^{x} R e^{-\frac{p t}{100}} d t$, which represents the exact value (Đuričin et al., 2018) considered rent in time $t=0$. In a special case, when the annual interest rate $p$ fixed, we have

$$
\int_{0}^{x} R e^{-\frac{p t}{100}} d t=R \int_{0}^{x} e^{-\frac{p t}{100}} d t=R\left[-\frac{100}{p} e^{-\frac{p t}{100}}\right]_{0}^{x}=R\left(-\frac{100}{p} e^{-\frac{p t}{100}}+\frac{100}{p}\right)
$$

Consequently, the current value of annuity dinars for the year, which runs on a continuous basis with continuous accumulation and $p=$ const., it is equal to

$$
A=R \cdot \frac{100}{p}\left(1-e^{-\frac{p x}{100}}\right)
$$

Obviously, $A$ is a simple time function $x$ and interest rate $p$. It's easy to see that $A$ depends on the $X$. It's evident that it is $A$ the bigger it is $X$ higher, i.e., that the present value of an annuity increases when a wider time interval (Duran et al., 2018). What's more, from the above relationship it follows that

$$
\lim _{x \rightarrow \infty} A=R \frac{100}{p} \text {. }
$$

This result is interesting because it shows that the present value of annuity in the continuous and discontinuous case is the same. Therefore, the current or present value (Mitrović et al., 2015) The eternal annuity does not depend on how this rent is made, nor how interest is calculated (continuously or discontinuously). 
It's easy to show that $A$ decreases when $P$ increases (and ${ }^{X}$ is fixed), or symbolically:

$$
\begin{aligned}
& \lim _{p \rightarrow \infty} A=0, \text { since it is } \\
& \lim _{p \rightarrow \infty} A=\lim _{p \rightarrow \infty} R \frac{100}{p} \cdot \lim _{p \rightarrow \infty}\left(1-e^{-\frac{p x}{100}}\right)=0(1-0)=0 .
\end{aligned}
$$

It follows that, in a continuous, as well as in a discounted case, the present value of annuities decreases when the interest rate rises.

\section{Conclusions}

In addition to these methods, there are a number of procedures for integrating certain types of integrals. It is, of course, more difficult to integrate than to differentiate. So, after all, with many other inverse operations. It is harder, for example, to reduce or log in than to scale. As the second root of the negative real number is not a real number, so the integral of some simple functions does not have a solution in the domain of elementary functions.

The primary aim of the agroeconomic implementation of an introductory integral lays in solving certain agroeconomic changes such as: increasing the productivity and economic strength of households, the quality of life for the agricultural and rural population and sustainable rural development. Implementing these measures requires a significant increase of budget funding and a greater exploitation of competent both European and worldwide agricultural and rural development help funds. If the methodological basis of the quantitative analysis is properly applied in the process of making and implementing the decisions, it must be followed by strengthening of institutions, infrastructural development, increasing the size of households, mechanization and equipment modernization and training of agricultural workers.

The agrarian policy should be harmonized with the industrial policy, thus impacting a more efficient development of the food industry and exporting. The application of integration in certain agroeconomic functions could find its implementation in modernization and better capacity exploitation, strengthening the ties between raw materials manufacturers and processors, and production diversification significantly increase the comparative advantages of agriculture, food self-reliability and the overall supply of services and goods.

The scientific contribution of this paper lies in a essential explanation of the integral account and an introductory integral implementation in agriculture and food industry development, as well as to mark the potentials and perspectives of its application toward more individual areas, in order to put in use the comparative advantages of agriculture.

It has practical application and can be used in the decision-making process, respecting agrarian and industrial policies. If the method of applying an integral account is correctly set, it allows the management to make timely and optimal business decisions in order to fulfill its objectives, in a longer time span. 


\section{Conflict of interests}

The authors declare no conflict of interest.

\section{References}

1. Atash, A. A., Bellehaj, S. H. (2017). General integral formulas involving Hubert hypergeometric functions of two variables. Mathematica Moravica, 21(2), 75-84.

2. Babić, Z., Aljinović, Z. (1996). Ekonomska matematika. Ekonomski fakultet, Split [In English: Babić, Z., Aljinović, Z. (1996). Economic Mathetmatics. Faculty of Economics, Split].

3. Cervi, G. R., Esperancini, M. S. T., Bueno, O. de C. Pinotti, B. E., (2010). Analysis of economic break-even point of the biogas utilization for electrical power conversion: case study in a swine terminated unit. $7 \mathrm{CBPE}$ : Brazilian congress of energetic planning, Sao Paulo, Itajuba, MG Brazil

4. Durkalić, D., Curčić, M. (2019). Mutual influence of the international investment position and the net government position with the banking sector of the Republic of Serbia. Ekonomika, 65(1), 95-106.

5. Damnjanović, R., Đurković, V., Miljković, M. (2018). Određeni integral u ekonomskim funkcijama. Oditor - časopis za Menadžment, finansije i pravo, 4(3), pp. 71-81 [In English: Damnjanović, R., Đurković, V., Miljković, M. (2018). A Certain Integral In Economic Functions. Oditor - Journal of Management, Finance and Law, 4(3), 71-81].

6. Deže, J. (2008). Agroekonomika - priručnik, Poljoprivredni fakultet Sveučilišta J.J. Strossmayera, Osijek [In English: Deže, J. (2008). Agroeconomics - manual, Agricultural Faculty of the University J.J. Strossmayera, Osijek].

7. Drenovak M. (1999). Privredna i finansijska matematika. Modeli i algoritmi, Komino trade, Kragujevac [In English: Drenovak M. (1999). Economic and Financial Mathematics. Models and Algorithms, Komino trade, Kragujevac].

8. Duran, U., Acikgoz, M. (2018). Apostol type (p, q): Frobenius-Euler polynomials and numbers. Journal of Mathematics, 42(4), 555-567.

9. Đuričin, S., Beraha I., Bodroža, D. (2018). Alternatives for exiting the loss zone for medium-sized agricultural enterprises in the Republic of Serbia. Economic of agriculture, 65(1), 391-411.

10. FAO, UNIDO, IFAD (2008). Report of the Global Agro-Industries Forum, Improving Competitiveness and Development Impact. FAO, Rome, pp. 6.

11. Ivović M. (1999). Finansijska matematika u neinflacionim i inflacionim uslovima. Ekonomski fakultet, Beograd [In English: Ivović M. (1999). Financial Mathematics in Non-Inflationary and Inflationary Conditionos. Faculty of Economics, Beograd].

12. Jovanović, D., Milenković, N., Damnjanović, R. (2017). Ocenjivanje i predviđanje potreba potrošača. Oditor - časopis za Menadžment, finansije i pravo, 3(1), 70-79 [In English: Jovanović, D., Milenković, N., Damnjanović, R. (2017). Evaluating and forecasting consumer needs. Oditor - Journal of Management, Finance and Law, 3(1), 70-79]. 
13. Knežević S., Mitrović S., Ilić A. (2016). Different perspectives on the cash flow statement. Hotel and Tourism Management, 4(2), 48-54.

14. Kožul, N. (2017). Tržišna cena rizika. Bankarstvo, 46(1), 58-67 [In English: Kožul, N. (2017). Market Risk Price. Banking, 46(1), 58-67].

15. Leković M., Cvijanović D., Jakšić M. (2018). Farmland real estate investment trusts. Economic of agriculture, 65(2), 745-755.

16. Markova, E. V., Sidler, I. V. (2019). Numerical solution of the age structure optimization problem for basic types of power plants.Yugoslav Journal of Operations Research, 29(1), 81-92.

17. Martić, Lj. (1976). Primjena matematičkih metoda u ekonomskoj analizi - Zbirka zadataka, Informator, Zagreb [In English: Martić, Lj. (1976). Application of Mathematical Methods in Economic Analysis - Collection of Tasks. Informator, Zagreb].

18. Mitrović A., Knežević S., Veličković M. (2015). Ratio analysis specifics of the family dairies' financial statements. Economic of agriculture, 62(4), 1061-1078.

19. Savić, Lj., Bošković, G., Mićić, V. (2016). Agroindustrija Srbije - potencijali i perspective, Ekonomika poljoprivrede, 63(1), 107-122 [In English: Savić, Lj., Bošković, G., Mićić, V. (2016). Agro Industry Of Serbia - Potentials And Perspectives, Economics Of Agriculture, 63(1), 107-122].

20. Wohlmuth, K., Kormawa, P.M. (2012). Context of Agro-industry in Africa. Agribusiness for Africa's Prosperity - Country Case Studies, UNIDO, Vienna, pp. 7 . 